\title{
Chapter 12 \\ Advancing Learning Cities: Lifelong \\ Learning and the Creation of a Learning \\ Society
}

\author{
David Atchoarena and Alex Howells
}

\section{Abbreviations}

$\begin{array}{ll}\text { EC } & \text { European Commission } \\ \text { GNLC } & \text { Global Network of Learning Cities } \\ \text { ICLC } & \text { International Conference on Learning Cities } \\ \text { ISCE } & \text { International Standard Classification of Education } \\ \text { OECD } & \text { Organisation for Economic Co-operation and Development } \\ \text { SDGs } & \text { Sustainable Development Goals } \\ \text { UIL } & \text { UNESCO Institute for Lifelong Learning } \\ \text { UNESCO } & \text { United Nations Educational, Scientific and Cultural Organization }\end{array}$

\subsection{Introduction}

As the world grapples with the most profound public health challenge in a century in the form of the coronavirus disease (COVID-19), humanity is also coming to terms with a number of potentially epoch-defining transformations, including the climate crisis, demographic change, technological transformation as part of the fourth industrial revolution or Industry 4.0, and artificial intelligence, all of which impact on transforming the new world of work. While lifelong learning is not a perfect solution, it has a key role to play in responding to these challenges and achieving sustainable economic and social development that is also fair and inclusive.

D. Atchoarena $(\varangle) \cdot$ A. Howells

UNESCO Institute for Lifelong Learning, Hamburg, Germany

e-mail: d.atchoarena@unesco.org

A. Howells

e-mail: a.howells@unesco.org

$\mathrm{S}$. Ra et al. (eds.), Powering a Learning Society During an Age of Disruption,

Education in the Asia-Pacific Region: Issues, Concerns and Prospects 58,

https://doi.org/10.1007/978-981-16-0983-1_12 
Lifelong learning is a multifaceted concept shaped by decades of policy debate and a mixed record of intervention at the country level. Lifelong learning calls for holistic investment in learning opportunities for all, across the whole life span; demands an open environment for access; and requires a system of incentives that encourages individuals and communities to become autonomous learners. Such enabling conditions allow the promotion of flexible transitions between education and work, support professional development, and foster physical and mental well-being, which are essential during a health emergency and everyday life.

Those global trends and challenges are felt in urban and rural areas alike, yet, in combination, they manifest with particular intensity in cities. By virtue of their larger populations of people concentrated in small geographical areas, cities epitomize humanity's susceptibility to, and potential to overcome, these wide-ranging challenges. Though they vary in size as well as in their cultural, social, economic, and political structures, cities have many common characteristics that determine and shape urban development. As a result, certain principles of action and policy features are equally relevant and applicable to a wide range of cities in a diversity of development contexts. This is the rationale behind international networks of cities such as the United Nations Educational, Scientific and Cultural Organization (UNESCO) Global Network of Learning Cities (GNLC). Member cities of the GNLC have made a commitment to lifelong learning. Regardless of size, demographic composition, political orientation or history, learning cities across world regions are determined to revitalize learning in their communities, at home and in work, while ensuring opportunities are equitable and accessible to all. Inclusion is more than a rhetorical aspiration: the GNLC encourages learning cities to establish the necessary infrastructure for the inclusion of vulnerable populations, such as migrants, youth at risk, elderly people, digitally excluded populations and people with disabilities, with a particular attention to gender equality.

Within the framework of the GNLC, a comprehensive understanding of the learning cities concept acknowledges a set of core values that should unite all member cities and guide their policies. They include an aspiration to the right to lifelong learning, active and global citizenship, and local democracy. Furthermore, in the midst of the global pandemic, resilience and recovery have also emerged as critical dimensions of learning cities' values and activities. Translating these dimensions into concrete policies and actions requires participatory, cross-sectoral processes. By working in this way, learning cities are putting in place the foundations of a learning society.

This chapter discusses the concept of lifelong learning, its emergence, recent developments, and implementation through public policies. Following an analysis of some of the most promising innovations to promote lifelong learning, particular focus is placed on the territorial approach or the concept of learning cities, which then fosters the establishment of a learning society. 


\subsection{Lifelong Learning: From Utopia to Reality, from Education to Capabilities}

The concept of learning cities, operationalized by frameworks such as the GNLC, has far-reaching dimensions beyond education, which can be drawn upon in a forward-looking way to advance lifelong learning at the local level. Those dimensions include the right to lifelong learning, learner engagement, citizenship and local democracy, and resilience and recovery. The last two are particularly relevant in the context of the COVID-19 pandemic. When cities advance in these dimensions, they establish the foundations necessary to build a learning society and promote sustainable development.

Lifelong learning is not a new concept. It has been part of policy debates in the fields of education and employment for decades. Following the adoption in 2015 of the 2030 Agenda for Sustainable Development, including Sustainable Development Goal (SDG) 4 on education, which promotes lifelong learning opportunities for all, the concept constitutes a benchmark for designing and reforming education systems and policies; and builds a bridge between education and other sectors, notably employment and social protection (UNESCO 2016). Lifelong learning is not just an extension of the learning process initiated at school, but involves linking learning with all domains of life, including work, family, citizenship, and personal development. In that sense, it is truly life-wide. This broad perspective also highlights the diversity of learning environments and experiences, usually categorized as formal, nonformal, and informal.

The formal categorization is defined in the International Standard Classification of Education 2011 developed by the UNESCO Institute for Statistics (UIS 2012), which describes formal education as "institutionalised, intentional and planned through public organizations and recognised private bodies" (UIS 2012, p. 11). Participation in formal education, which also includes vocational education, special needs education, and some parts of adult education, is often called initial education, meaning participation in formal education before entering the labor market.

Nonformal education is also an institutionalized form of learning that is intentional and planned by an education provider but defined as complementing or substituting formal education. Meanwhile, informal learning is intentional, but not institutionalized. Informal learning may include learning activities that occur in the family, at work, or in the community, as well as self-directed forms of learning. It is distinct from incidental or random learning that results from ordinary life activities, or from participating in events that are not designed as educational activities.

In reality, it is not always easy to clearly differentiate these three categories of learning. Boundaries can be fine and at times blurred, especially considering the rise of digital provision. More and more, lifelong learning is described as a continuum that integrates throughout life various types of education activities, which are characterized by diverse degrees of formalization; and which correspond to a wide range of goals, including education, employment, civic engagement, personal 
development, and entertainment. This is sometimes described as a biography of learning.

\subsubsection{The Individual Approach}

Increasingly, the concept of lifelong learning is becoming learner-centered. The focus is placed on the individual and the way one's own learning pathway is built throughout life, articulating the learning process to different life contexts. The interaction between education and its application in real-life situations gives a sense of purpose to lifelong learning. The concept of adaptation has often been used to describe this goal-adaptation to the labor market, to society, to life; and increasingly, the focus on individuals is combined with an emphasis on autonomy. The challenge is not only to ensure that individuals can adapt to a changing environment, but to give them the capacity to choose their learning experience in terms of pathway and content, and eventually to shape their future at work, as active citizens, and through their life choices. From that perspective, lifelong learning can be seen as a unifying concept that brings together different dimensions: education, work, family, citizenship, personal development. This vision is gradually being translated in policy instruments that open access to a range of social rights for individuals.

\subsubsection{The Social Approach}

While the learner-centered approach remains topical, the social dimension continues to play a key role in shaping public policies:

(i) In the 1960s, industrialized countries, facing major changes on the labor market and guided by the modernization ideology, introduced deep education reforms to drive and accommodate the trends toward massification and developed adult education programs, notably to provide a "second chance" to people with low levels of education. As a result, the scope of public policies in education went beyond schooling (or the formal system and initial education) to encompass a diversity of programs and aim at various objectives.

(ii) In the 1990s, in Europe, the adoption of the White Paper on Education and Training: Teaching and Learning-Towards the Learning Society (European Commission 1995) prompted a new approach to lifelong learning in industrialized countries inspired by the acceleration and deepening of changes, particularly in the population (aging, migration); and in the labor market (employment shift toward services, structural unemployment issues). Furthermore, the discourse on the knowledge economy and the knowledge society (Bindé 2005) increasingly placed lifelong learning at the core of the agenda for competitiveness, investing in human capital, and in cultural capital, 
forming part of the policy mix implemented by an increasing number of countries. Hence, lifelong learning tended to become an imperative to upskill and reskill the workforce, particularly workers with low levels of qualification.

Despite the deep transformation of the labor market and the end of stable, active lifelong employment in the formal economy as the norm, work remains key to social inclusion. Hence, lifelong learning has been increasingly incorporated within social protection policies, to prevent labor market exclusion that eventually leads to social exclusion. The concept of flexicurity ${ }^{1}$ illustrates this approach, which transcends the former rationale for second-chance education: in an increasingly unpredictable and rapidly changing labor market, as reflected in Industry 4.0, flexibility and security is needed for all, so is lifelong learning (International Labour Organization 2019). In developing economies where informality remains the norm for most of the active population, opening up learning opportunities throughout life and introducing mechanisms to recognize informal learning can contribute to de-segment dualized labor markets.

\subsubsection{The "5th Pillar" Approach}

Besides the conventional dichotomy between the individual approach and the social approach, the vision of lifelong learning today is also shaped by new developments in teaching and learning processes, and the rise of new pedagogies. The centrality of the learner, a slogan largely adopted in the formal system, also drives the provision of lifelong learning opportunities and the learning processes throughout life. The disruption that technology introduced in provision and participation patterns potentially offers unlimited opportunities to individuals to engage in self-directed learning and to get their learning outcomes certified through micro-credentials. With technology, informal education tends to become the driving force of lifelong learning. In addition, methodologies and tools for knowledge capitalization have been instrumental in facilitating learning pathways.

Making learning outcomes visible is particularly important for the most disadvantaged groups, or those who do not hold a qualification. Hence, the gradual design of mechanisms and procedures to assess, validate, and recognize learning outcomes, including prior learning, has truly been a transformative process to open the way to lifelong learning pathways, and to promote inclusion. Recognition, validation, and accreditation of nonformal and informal learning forms one of the pillars of effective lifelong learning policies (Singh 2012), increasing employability, encouraging further learning, and constituting a form of social recognition for those

\footnotetext{
${ }^{1}$ Initially introduced in Demark in the 1990s, "flexicurity" is defined by the European Commission (2007, p. 5) as a means to "create more and better jobs, modernise labour markets, and promote good work", with four main components listed as "flexible and reliable contractual arrangements, comprehensive lifelong learning strategies, effective active labour market policies, and modern, adequate and sustainable social protection systems."
} 
left behind by the school system. Within that framework, learning to learn, sometimes called the "5th pillar" 2 of education, emerged as a key competency for learners of all ages. Hence, more than a new pedagogy, placing the learner at the center has become a new philosophy for designing lifelong learning policies and systems. This is not only about acquiring knowledge, skills, competencies, and possibly achieving a qualification, it is about empowering people. This philosophy also reconciles the individual with the social rationale, and involves granting new rights to individuals as well as providing the policy environments and the institutional opportunities that allow them to exercise those.

On the provision side, those developments required the creation of new functions. Providers are no longer only expected to teach, and offer content and tutorials, they are also increasingly responsible for information, guidance, and counselling through methodologies similar to coaching. The rapid development of artificial intelligence is likely to fundamentally transform those functions by developing technology-driven individualized services accessible through digital modes, enabling people to follow and inform learning patterns throughout life.

\subsubsection{The Legal Approach}

Beyond introducing new learning rights in education, the most significant policy developments are labor and social laws, which reflect an integrative approach, combining all those dimensions in comprehensive instruments such as the "compte personnel d'activité" (individual activity account) in France, which includes three elements: training, protection, and civic engagement. In Singapore, SkillsFuture offers comprehensive opportunities for all to access lifelong learning at different stages of their lives through a holistic system of education and training that includes, for instance, a universal learning credit.

Today, lifelong learning goes much further than ensuring learning opportunities to all throughout life. It reflects a societal vision based on a focus on learners considered in their complexity (students, workers, family members, citizens) and on inclusion, via redistributive mechanisms giving more opportunities and support to the most disadvantaged. This logic of empowerment eventually displaced the discourse from a human rights approach to a focus on capabilities as defined by Amartya Sen (2005).

Finally, another key dimension of the recent developments in lifelong learning is the rise of a territorial approach (OECD 2020), exemplified by the emergence of learning cities as a concept, a policy, and a social practice.

\footnotetext{
${ }^{2}$ Reference to the four pillars of education: learning to know, learning to do, learning to live together, learning to be (Delors et al. 1996).
} 


\subsection{The "Learning City" and Its Implementation Through the Global Network of Learning Cities}

Educating cities was the theme of two OECD conferences, in Barcelona in 1989, and in Gothenburg in 1992. The discussions and analyses that took place during those meetings inspired the publication City Strategies for Lifelong Learning (OECD 1992). Cooperation between the municipal government, local learning institutions, and the private sector-with the aim of addressing the human resource demands of the city's economy - was identified as a key success factor. In this framework, the concept of learning placed emphasis on improving the economy and the labor market.

In 1996, the European Year of Lifelong Learning resulted in the launch in the United Kingdom of the Learning Cities Network, which aims to encourage and support lifelong learning. In the 3 decades since, an increasing number of countries around world have established national networks of learning cities, including the People's Republic of China, the Republic of Korea, and Mexico.

\subsubsection{Learning Cities and the Sustainable Development Goals}

Learning cities are urban entities committed to promote lifelong learning for all, as a manifestation of the right to education and as an instrument to achieve sustainable development. They do this by uniting the actions of a wide range of stakeholders and by mobilizing resources to promote inclusive learning at all levels of education. This includes establishing networks of education and training institutions at the local level, revitalizing learning in families and communities, encouraging workplace learning, and extending connectivity and the use of technology.

In recent years, UNESCO has played an active role in promoting the concept of learning cities as a strategy in making lifelong learning available to all. ${ }^{3}$ The fundamental elements of what constitutes a learning city for UNESCO are defined in the 2013 Beijing Declaration on Building Learning Cities (UIL 2013a), which also confirmed the role of the GNLC as a hub of intercity exchange and as a framework for the promotion of lifelong learning in cities (UIL 2015). The "culture of learning throughout life" enshrined in the Beijing Declaration is also the clarion call of UIL's future-oriented report, Embracing a Culture of Lifelong Learning (UIL 2020).

Despite the disruption caused by the COVID-19 pandemic, countries continue to strive for sustainable development for people, for the planet, and for prosperity. Countries' commitment to the United Nations 2030 Agenda for Sustainable Development and its 17 SDGs is pressing, with only 10 years left to achieve them. Lifelong learning is a key principle of SDG 4, yet has wide-ranging, cross-cutting

\footnotetext{
${ }^{3}$ Source UIL. Forthcoming. Making lifelong learning a reality: a handbook. Hamburg.
} 
implications for all 17 SDGs. There is an increasing understanding, for example, of how education (SDG 4), health (SDG 3), and gender (SDG 5) are linked by lifelong learning (English and Carlsen 2019). More broadly, lifelong learning opportunities for all engender progress in all areas of development, including also the SDGs related to poverty, hunger, work, responsible consumption, climate, and peace (International Council for Science and International Social Science Council 2015).

Furthermore, just as lifelong learning has its own "dedicated" goal in SDG 4, so too do cities in SDG 11 ("make cities inclusive, safe, resilient and sustainable"). The importance of cities to the 2030 Agenda has been at the heart of debates on local and urban sustainability (Doll 2015; Sustainable Development Solutions Network 2016; OECD 2020; Woodbridge 2016). With a focus on multilevel governance in cities in the context of decentralization, these debates highlight the importance of civic engagement in local decision making, the centrality of planning for mainstreaming the SDGs in local strategies, and the need to facilitate connections and peer learning with other cities. Those are also some of the directions that the GNLC attempts to promote.

\subsubsection{The Global Network of Learning Cities}

The GNLC was formally established by UNESCO in 2012 but opened to applications for membership in 2015. Since then, the GNLC has welcomed a new cohort of cities each year committed to promoting lifelong learning through dedicated policies, programs, and practices, while also mainstreaming lifelong learning in urban policies for sustainable development. Regular exchanges have made the network a vibrant entity, with the International Conference on Learning Cities organized periodically to bring city representatives and education stakeholders together. The first ICLC took place in 2013 in Beijing, where the foundational declaration was endorsed. The subsequent International Conferences on Learning Cities took place in 2015 at Mexico City; in 2017 at Cork, Ireland; and in 2019 at Medellín, Colombia, in which learning cities adopted the Medellín Manifesto, a pledge to boost inclusion (UIL 2019).

The fourth ICLC in Medellín also adopted a strategy for the network to further promote policy dialogue, best practice exchange, peer learning, partnership, and capacity building. To guide cities in advancing their lifelong learning agenda, the GNLC developed monitoring and planning tools. In 2015, a set of Guidelines for Building Learning Cities was published, containing practical recommendations for aspiring learning cities focused on six areas: planning, involvement, celebration, accessibility, monitoring and evaluation, and funding (UIL 2015). In 2013, the network issued the Key Features of Learning Cities (UIL 2013b) as an indicative instrument for measuring learning cities' progress in becoming learning cities. These features relate to (i) the wider benefits of building learning cities, (ii) the major building blocks of learning cities, and (iii) the fundamental conditions for building learning cities. Across these three categories, there are 42 features with 
suggested indicators and data sources, including quantitative as well as qualitative data. By measuring their progress toward the 42 features, learning cities can identify their strengths and areas for improvement, thus marking tangible milestones in a continuous learning city process.

In the context of COVID-19, the GNLC has facilitated exchange on learning cities' responses to the pandemic, creating a platform for mutual learning at a time when severe restrictions on public life have been imposed. Learning cities have demonstrated how, during the crisis, they were able to mobilize distance education technology; higher education institutions; family and intergenerational learning practices; and the cultural sector to sustain access to learning, maintain the social fabric, increase health awareness and prevention, and reskill workers for tomorrow's labor market. Such measures illustrate how cities have responded by using lifelong learning to develop emergency responses, prepare recovery, and foster resilience. ${ }^{4}$ A selection of interesting initiatives have been compiled in a publication, Snapshots of Learning Cities' Responses to COVID-19, ${ }^{5}$ which provides an insight into 13 initiatives from cities around the world and how they were set up during a time of crisis.

The learning city model at the heart of the GNLC has been the subject of much discussion in academia, civil society, and international organizations. It provides a globally applicable framework for cities to come to grips with the concept and its application. The editorial of the Oxford Review of Education's 2019 special issue on learning cities flags some of the arguments against, and potential pitfalls of, normative learning city models, i.e., that they may tend to prioritize certain forms of education and training based on an economic rationale and neglect other domains; that the governance approaches they promote could result in giving too much emphasis on planning while neglecting actual practices; and that international networks, benchmarks and indicators might encourage cities to conform to a vision far from their reality (Facer and Buchczyk 2019).

As a normative framework, the GNLC is indeed subject to such risks. However, the approach the network takes encourages an inclusive, collaborative, and humanistic understanding of the learning city model. With lifelong learning at its core, the network highlights the value of every learning endeavor, whether aimed at economic development, community cohesion, career development, or simply enjoyment; and regardless of where it takes place-school, workplace, community, family, or online. Moreover, the network's approach clearly places learning at the core of sustainable development (Ofei-Manu et al. 2018). It does advocate a governance approach, but one that is multilevel in nature, influenced by bottom-up processes and inclusive of learners, community groups, local organizations, businesses, and government.

Finally, the Key Features of Learning Cities, sometimes considered as benchmarks, constitute a comprehensive and indicative instrument that learning cities

\footnotetext{
${ }^{4}$ Source UNESCO Institute for Lifelong Learning. GNLC webinars: UNESCO learning cities' response to COVID-19. https://uil.unesco.org/lifelong-learning/learning-cities/gnlc-webinars-une sco-learning-cities-response-covid-19.

${ }^{5}$ Source UIL. Forthcoming. Snapshots of learning cities' responses to COVID-19. Hamburg.
} 
are invited to use as long as it helps them get a sense of their own development. This has been acknowledged in the development of other instruments to measure learning city development. Learning city indicators allow cities to gauge strengths and weaknesses in implementing a lifelong learning strategy at the local level. However, they are used in a way that takes cognizance of each city's unique context (Preisinger-Kleine 2013). The attraction of the GNLC is evident in its continued growth and in the make-up of its membership: cities from various regions and development contexts, with different socioeconomic statuses, demographics, and political outlooks. Cities as diverse as Shanghai in the People's Republic of China, Espoo in Finland, and Huejotzingo in Mexico have joined the network, contribute to its activities, and benefit from the opportunities it creates for exchange and learning. This is the universal significance of an international learning city network.

\subsection{Advancing Learning Cities to Build a Learning Society}

UIL's report Embracing a Culture of Lifelong Learning (UIL 2020, p. 35) makes the case for establishing lifelong learning as a human right: "The right to education must be renewed, reaffirming lifelong learning as human right. This right is thus no longer limited to accessing the school system, but rather serves to guarantee continuity of learning throughout life, including relevant guidance and digitally portable assessment of all learning outcomes." Lifelong learning should therefore be seen as an individual and a social right and, in the context of climate change, as a public good in environmental terms as well. It involves caring for oneself, for others and for the planet (UIL 2020).

The right to lifelong learning is an ideal that can be made tangible through social inclusion and inclusive education. Social inclusion in cities ensures that citizens are involved in decision-making processes and have access to public services, including education. Inclusive education aims at involving all-with a particular focus on vulnerable groups-in learning opportunities. In this framework, the concept of access goes beyond the traditional education institutions (schools, universities, community learning centers, vocational training institutions) to include a wide diversity of spaces likely to become learning places, such as libraries, museums, workplaces, digital spaces, and private homes, through the promotion of family and intergenerational learning (UIL 2020). The topic is explored in depth, with examples from cities around the world, in UIL's upcoming publication, Inclusive Lifelong Learning in Cities: Policies and Practices for Vulnerable Groups. ${ }^{6}$

Learner engagement, citizenship, and local democracy constitute another fundamental dimension of the learning cities concept. Cities have been an important reference point for thinking through questions of citizenship and democracy (Biesta and Cowell 2016). Democratic control of local resources; the role of local

\footnotetext{
${ }^{6}$ Source UIL. Forthcoming. Inclusive lifelong learning in cities: policies and practices for vulnerable groups. Hamburg.
} 
governments in wealth redistribution to favor inclusion; and their capacity to care for people, communities, and the learning needs of all are some of the attributes expected from learning cities. Reclaiming of the city, its space, its planning, and its ability to remake itself in the interest of all are some of challenges that learning cities have to face. While similar ideals can be found in national policies, their reinterpretation and ownership at the city level, in a context of decentralized governance and civic engagement, have a considerable potential to accommodate and be shaped by the needs and aspirations of local people. This capacity is enhanced when an understanding of the learning cities concept incorporates associated forms of collective learning at the micro level within and around the city, including study circles, family learning, learning communities, learning villages, learning neighborhoods, and learning territories (James et al. 2018).

All these types of bottom-up, community-led learning contribute to building a learning society. They are often spontaneous in nature and reflect an attempt to mobilize knowledge to respond to local development and sustainability issues; for example, initiatives to improve recycling practices or preserve local green spaces, and campaigns to prevent gender-based violence and improve women's and children's health. Such responses have been mushrooming in the context of the COVID-19 pandemic where communities, supporting and sometimes substituting government efforts, have contributed to disseminating health information, coordinating local deliveries, and organizing online learning communities.

Such community responses value the social advantages of learning while enriching and benefiting from the learning cities concept. In turn, learning cities value socially oriented learning due to its positive impact on community cohesion. As well as encouraging these forms of learning at the micro level, learning cities see great worth in creating connections between community groups, institutions, and industries. Hence, cities that have operationalized the learning cities concept have fostered partnerships between civil society organizations, education and training institutions, employers, and the public sector. Those partnerships enable people to connect their learning experiences to everyday life, articulate their learning demands, build their own agency to choose, and construct individualized learning pathways (UIL 2020). This empowerment of individuals not only increases their engagement in lifelong learning and in the life of the city, but also contributes to strengthen local democracy.

Resilience and recovery constitute another important dimension in considering the future of learning cities. The effect of learning on "urban resilience" has been discussed in academic literature for a number of years, often in terms of local people's capacity to identify and respond to disruption in the event of a major disaster (Robin et al. 2019). The notion of resilience in cities is captured by SDG 11 and reiterated in Learning Cities and the SDGs: A Guide to Action (UIL 2017) in an approach to link global goals to local communities. The recent contribution by Robin et al. (2019) on urban crisis in the city of Cape Town found that crisis management processes resulted in knowledge being formally documented and disseminated, the formation of new multi-stakeholder networks, and the potential for new knowledge networks to shape learning during and after the crisis. Such examples suggest that learning cities are prompted by crises to develop their capacity for resilience. In the long term, resilience 
should be a priority for learning cities, as resilience equips local infrastructure and people with the ability to adapt rapidly to changing circumstances, which can only be an asset in an era of increasing uncertainty.

Resilience in learning cities_particularly resilience in connection with recovery-has taken on a new significance as a result of the COVID-19 pandemic. In June 2020, a UNESCO meeting on Urban Solutions: Learning from Cities' Responses to COVID-19 considered how, in responding to COVID-19, cities can transform in "meaningful ways that not only protect vulnerable people from immediate threats but also build resilience for the looming climate crisis and other emergencies." It also discussed how stakeholders in cities can "rethink their urban policies to strengthen their risk preparedness and response capacity, and become more resilient by making cities smarter, greener, more inclusive and resilient" (UNESCO 2020, p. 6). A webinar organized by the GNLC on strategies for recovery from the COVID-19 pandemic identified planning the implementation of responses, including for the emergency phase, and articulating various levels of jurisdiction within decentralized systems as key for recovery. ${ }^{7}$

In various parts of the world, COVID-19 has generated mistrust between citizens and institutions, and sometimes increased domestic and urban violence. Cities have had to develop conflict prevention and conflict resolution mechanisms to address these threats, often affecting, in particular, the most vulnerable: children and women. Learning to live together and the consolidation of peace are essential to having resilient cities and communities. To that effect, promoting citizen participation to design solutions has been at the center of efforts for many learning cities. Based on the steadfast commitment of politicians and administrators, learning cities encourage a participatory approach and include different voices in public decision making, particularly by engaging in a continuous and open dialogue with civil society. Many local governments have already advanced strategies for the enhancement of involvement in decision making processes. Citizens are encouraged to engage in a great variety of initiatives and models, such as neighborhood committees, youth councils, and participatory budgeting (UN-Habitat 2015).

These challenges influence a learning city's capacity to recover from a major disruption such as the COVID-19 pandemic and will eventually determine its progress toward a more resilient future and a learning society.

\subsection{COVID-19: A “Stress Test" for Learning Cities, a Lesson for the Learning Society}

Re-imagining learning cities and their contribution to lifelong learning in the age of COVID-19 is what is at stake today. In this framework, advancing the concept of

\footnotetext{
${ }^{7}$ UNESCO. UNESCO learning cities' responses to COVID-19-Outcomes of webinar on 27 May. https://uil.unesco.org/lifelong-learning/learning-cities/unesco-learning-cities-responsescovid-19-outcomes-webinar-27-may.
} 
learning cities requires that we deepen some of the guiding principles and design new practical steps within the framework of integrated urban policies to pave the way to a learning society.

Placing inclusion first has emerged as a priority everywhere in the world, while in the midst of the pandemic, structural inequality appeared more than ever as one of the major obstacles to lifelong learning, blocking the path to sustainable development. To this mirror effect, which resulted in increasing policy attention on the issue, the pandemic amplified the deepening, existing inequalities and added new ones. In this context, disadvantaged groups such as young people and older adults at risk, people suffering from disabilities, and refugees deserve priority attention, with reinforced consideration for gender equality. Working with other levels of governance, including the central level, municipal governments have a key role to play in guaranteeing universal access to basic services for all, especially the vulnerable groups, starting with health and education.

Increasingly, learning cities must also become smart cities. The way in which technology emerged as a compulsory resort to ensure the continuity of teaching and learning during the pandemic highlighted the need to address connectivity issues and access to digital networks, devices, and educational resources. Learning cities have often been creative in contributing to ensuring that all learners would continue to have access to education through distance modes, including online. Many also faced severe limitations due to the lack of connectivity, shortage of equipment and content, low levels of digital literacy among learners, and lack of digital skills within the teaching force. The concept of smart cities has often been driven by technology, and learning cities are ideally placed to redefine this notion and place it at the service of open access to digital educational tools and resources to offer lifelong learning opportunities for all.

Reconsidering governance models constitutes another necessary dimension of our response to the challenges ahead. The COVID-19 pandemic has revealed the limitations of conventional governance models in terms of coordination between departments across sectors and levels of governance, and in the way public services are provided, including education. The need to design integrated responses able to address diverse but interconnected needs (food security, health, social protection, education, work, etc.) has become a necessity for cities.

Learning cities provide an opportunity to rethink civic engagement, citizenship, and democratic participation in the light of urban dynamics. The COVID-19 crisis gave new impetus to an already vibrant debate on the transformation of current democratic models in a way that allows local governments, which are best placed to develop an understanding of urban problems at the "human scale", to have their voices heard at the national level. While the pandemic has, in many cases, deepened the divide between citizens and institutions, forms of democratic participation at the local levels provide an opportunity to rebuild trust between citizens and decision makers. Furthermore, the participative processes that have mushroomed at the local level during the crisis have enhanced community development, community work, and community education. Those experiences demonstrated the benefits to learning 
cities of giving priority to citizens, encouraging civic engagement, and supporting learning and engaged citizens.

Finally, advancing learning cities also require strengthening policy sharing, exchange of good practices, and peer learning. COVID-19 illustrated how local government networks, such as the GNLC, can quickly provide to their members information on effective strategies and measures to contain such crisis. As a platform for exchange of experiences, the network provided the space for learning cities to create new solutions for addressing some of the challenges that the pandemic has highlighted or created. It helped them to improve planning and delivery, from emergency responses to recovery, in all areas of public policy beyond health issues, and to place lifelong learning at the core of integrated responses. In so doing, they illustrated a broader principle that can lay the ground for building a learning society.

\section{References}

Biesta, G., and Cowell, G. 2016. Cities, citizenship and civic learning: Introduction to the special edition. Policy Futures in Education 14 (4): 427-430. https://doi.org/10.1177/147821031561 0260.

Bindé, J. 2005. Towards knowledge societies: UNESCO world report. Paris. https://unesdoc.une sco.org/ark:/48223/pf0000141843. Accessed 6 November 2020.

Carlsen, A., and G. Haddad. 2013. Introduction. International Review of Education 59 (3): 311-318. https://doi.org/10.1007/s11159-013-9371-3.

Delors, J. et al. 1996. Learning: The treasure within. Report to UNESCO of the International Commission on Education for the twenty-first century. Paris: UNESCO. https://unesdoc.unesco. org/ark:/48223/pf0000110780. Accessed 6 November 2020.

Doll, C. 2015. Cities should be at the heart of the SDGs. Tokyo: United Nations University. https:// unu.edu/publications/articles/cities-heart-of-sdgs.html. Accessed 6 November 2020.

English, L.M., and A. Carlsen. 2019. Lifelong learning and the Sustainable Development Goals (SDGs): Probing the implications and the effects. International Review of Education 65 (2): 205-211. https://doi.org/10.1007/s11159-019-09773-6.

European Commission. 1995. White paper on education and training: Teaching and learning - Owards the learning society. Brussels. https://op.europa.eu/en/publication-detail/-/pub lication/d0a8aa7a-5311-4eee-904c-98fa541108d8/language-en. Accessed 6 November 2020.

European Commission. 2007. Towards common principles of flexicurity-Draft council conclusions. Brussels: EC. Retrieved 26 November 2020 from https://data.consilium.europa.eu/doc/document/ ST-15497-2007-INIT/en/pdf.

Facer, K., and M. Buchczyk. 2019. Towards a research agenda for the "actually existing" learning city. Oxford Review of Education 45 (2): 151-167. https://doi.org/10.1080/03054985.2018.155 1990.

International Council for Science and International Social Science Council. 2015. Review of targets for the Sustainable Development Goals: The science perspective. Paris. https://council.science/ wp-content/uploads/2017/05/SDG-Report.pdf.

International Labour Organization. 2019. Work for a brighter future: Global commission on the future of work. Geneva. https://www.ilo.org/global/topics/future-of-work/publications/WCMS_6 62410/lang-en/index.htm. Accessed 6 November 2020.

James, J., J. Preece, and R. Valdés-Cotera (eds.). 2018. Entrepreneurial learning city regions: dDelivering on the UNESCO 2013, Beijing Declaration on Building Learning Cities. Cham: Springer. 
Organisation for Economic Co-operation and Development (OECD). 1992. City strategies for lifelong learning: A CERI/OECD study prepared for the Second Congress on Educating Cities, Gothenburg, November 1992. Paris: Centre for Educational Research and Innovation. http://www. oecd.org/education/innovation-education/34931642.pdf. Accessed 6 November 2020.

OECD. (2020). A territorial approach to the Sustainable Development Goals: Synthesis report. Paris. https://www.oecd.org/cfe/a-territorial-approach-to-the-sustainable-developmentgoals-e86fa715-en.htm. Accessed 6 November 2020.

Ofei-Manu, P., et al. 2018. How collaborative governance can facilitate quality learning for sustainability in cities: A comparative case study of Bristol, Kitakyushu and Tongyeong. International Review of Education 64 (3): 373-392. https://doi.org/10.1007/s11159-017-9667-9.

Preisinger-Kleine, R. 2013. An analytical quality framework for learning cities and regions. International Review of Education 59 (4): 521-538. https://doi.org/10.1007/s11159-013-9364-2.

Robin, E., et al. 2019. (Un)learning the city through crisis: Lessons from Cape Town. Oxford Review of Education 45 (2): 242-257. https://doi.org/10.1080/03054985.2018.1551197.

Sen, A. 2005. Human rights and capabilities. Journal of Human Development 6 (2): 151-166. https://www.tandfonline.com/doi/abs/10.1080/14649880500120491.

Singh, M. 2012. UNESCO guidelines for the recognition, validation and accreditation of the outcomes of non-formal and informal learning. Hamburg: UNESCO Institute for Lifelong Learning. https://unesdoc.unesco.org/ark:/48223/pf0000216360. Accessed 6 November 2020.

Sustainable Development Solutions Network. 2016. Getting started with the SDGs in cities: a guide for stakeholders. New York. https://resources.unsdsn.org/getting-started-with-the-sdgs-in-cities. Accessed 6 November 2020.

United Nations Educational, Scientific and Cultural Organization (UNESCO). UNESCO learning cities' responses to COVID-19-Outcomes of webinar on 27 May. https://uil.unesco.org/lifelonglearning/learning-cities/unesco-learning-cities-responses-covid-19-outcomes-webinar-27-may.

UNESCO. 2016. Education 2030: Incheon declaration and framework for action: Towards inclusive and equitable quality education for and lifelong learning for all. Paris. https://unesdoc.unesco. org/ark:/48223/pf0000243278. Accessed 6 November 2020.

UNESCO. 2020. Urban solutions: Learning from cities' responses to COVID-19: Online meeting report. Paris. https://unesdoc.unesco.org/ark:/48223/pf0000373940. Accessed 6 November 2020.

UNESCO Institute for Lifelong Learning (UIL). GNLC webinars: UNESCO learning cities' response to COVID-19. https://uil.unesco.org/lifelong-learning/learning-cities/gnlc-webinarsunesco-learning-cities-response-covid-19.

UIL. Forthcoming. Snapshots of learning cities' responses to COVID-19. Hamburg.

UIL. 2013a. Beijing Declaration on building learning cities lifelong learning for all: Promoting inclusion, prosperity and sustainability in cities. Adopted at the International Conference on Learning Cities in Beijing, People's Republic of China, 21-23 October 2013. Hamburg. https:// unesdoc.unesco.org/ark:/48223/pf0000226755. Accessed 6 November 2020.

UIL. 2013b. Key features of learning cities. Adopted at the International Conference on Learning Cities in Beijing. 21-23 October 2013, People's Republic of China. Hamburg. https://unesdoc. unesco.org/ark:/48223/pf0000226756. Accessed 6 November 2020.

UIL. 2015. Guidelines for building learning cities. Hamburg: UIL, UNESCO Global Network of Learning Cities. https://unesdoc.unesco.org/ark:/48223/pf0000234987. Accessed 6 November 2020.

UIL. 2017. Learning cities and the SDGs: A guide to action. Hamburg: UIL, UNESCO Global Network of Learning Cities. https://unesdoc.unesco.org/ark:/48223/pf0000260442. Accessed 6 November 2020.

UIL. 2019. Medellín Manifesto: learning cities for inclusion. Hamburg: UIL, UNESCO Global Network of Learning Cities. https://unesdoc.unesco.org/ark:/48223/pf0000371128. Accessed 6 November 2020.

UIL. 2020. Embracing a culture of lifelong learning: contribution to the futures of education initiative. Hamburg: UNESCO Global Network of Learning Cities. https://unesdoc.unesco.org/ ark:/48223/pf0000374112. Accessed 6 November 2020. 
UIL. Forthcoming. Inclusive lifelong learning in cities: Policies and practices for vulnerable groups. Hamburg.

UIL. Forthcoming. Making lifelong learning a reality: A handbook. Hamburg.

UNESCO Institute for Statistics. 2012. International standard classification of education: ISCED 2011. Montreal. https://unesdoc.unesco.org/ark:/48223/pf0000219109. Accessed 6 November 2020.

UN-Habitat. 2015. Urban governance. HABITAT III Issue Papers. No. 6. New York. https://uploads. habitat3.org/hb3/Habitat-III-Issue-Paper-6_Urban-Governance-2.0.pdf.

Woodbridge, M. 2016. Cities and the sustainable development goals. ICLEI Briefing Sheet Urban Issues. No. 02. Bonn: International Council for Local Environmental Initiatives (ICLEI) World Secretariat. http://old.iclei.org/fileadmin/PUBLICATIONS/Briefing_Sheets/SDGs/02_-_ICLEIBonn_Briefing_Sheet_-_SDGsandCities_2015_web.pdf.

The opinions expressed in this chapter are those of the author(s) and do not necessarily reflect the views of the Asian Development Bank, its Board of Directors, or the countries they represent.

Open Access This chapter is licensed under the terms of the Creative Commons Attribution-NonCommercial 3.0 IGO license (http://creativecommons.org/licenses/by-nc/3.0/igo/) which permits any noncommercial use, sharing, adaptation, distribution and reproduction in any medium or format, as long as you give appropriate credit to the Asian Development Bank, provide a link to the Creative Commons license and indicate if changes were made.

Any dispute related to the use of the works of the Asian Development Bank that cannot be settled amicably shall be submitted to arbitration pursuant to the UNCITRAL rules. The use of the Asian Development Bank's name for any purpose other than for attribution, and the use of the Asian Development Bank's logo, shall be subject to a separate written license agreement between the Asian Development Bank and the user and is not authorized as part of this CC-IGO license. Note that the link provided above includes additional terms and conditions of the license.

The images or other third party material in this chapter are included in the chapter's Creative Commons license, unless indicated otherwise in a credit line to the material. If material is not included in the chapter's Creative Commons license and your intended use is not permitted by statutory regulation or exceeds the permitted use, you will need to obtain permission directly from the copyright holder.

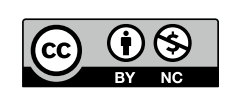

